https://ojs.umrah.ac.id/index.php/anugerah

\title{
Pelatihan Penulisan Karya Ilmiah untuk Meningkatkan Kemampuan Guru di SMP Negeri 7 Kota Bengkulu
}

\author{
Fina Hiasa ${ }^{1 *}$, Amril Canrhas ${ }^{2}$ \\ ${ }^{1,2}$ Universitas Bengkulu, Kota Bengkulu, Indonesia \\ *e-mail korespondensi: finahiasa@unib.ac.id \\ Pengiriman: 12 Oktober 2019; Diterima: 21 November 2019; Publikasi: 28 November 2019
}

\begin{abstract}
Abstrak
Tujuan dari pengabdian ini adalah meningkatkan kemampuan guru di SMPN 7 Kota Bengkulu dalam menulis karya ilmiah. Metode yang digunakan dalam kegiatan pegabdian ini adalah metode pelatihan dengan cara ceramah dan demonstrasi langsung bagi peserta pelatihan. Peserta dalam kegiatan ini adalah dewan guru SMP Negeri 7 Kota Bengkulu yang berjumlah 13 orang. Instrumen yang digunakan pada pelatihan ini adalah angket yang dibagikan kepada para peserta sebelum dan sesudah pelatihan untuk melihat ada atau tidaknya peningkatan pengetahuan peserta pelatihan. Pelatihan ini menghasilkan peningkatan pengetahuan guru tentang karya ilmiah yaitu pengetahuan daftar referensi dan jurnal publikasi sebesar 55\%, pengetahuan struktur karya ilmiah sebesar $40 \%$, pengetahuan teknik menulis karya ilmiah sebesar 50\%, dan kendala psikologis dan ekonomi sebesar $50 \%$.
\end{abstract}

Kata kunci: pelatihan; guru; karya ilmiah

\begin{abstract}
The purpose of this service is to improve the ability of teachers at SMPN 7 Bengkulu City in writing scientific papers. The method used in this pegabdian activity is a training method by way of lectures and direct demonstrations for trainees. Participants in this activity were the board of teachers of SMP Negeri 7 Bengkulu City, totaling 13 people. The instrument used in this training was a questionnaire that was distributed to participants before and after the training to see whether or not there was an increase in the knowledge of the trainees. This training resulted in an increase in teacher knowledge about scientific work, namely knowledge of reference lists and publication journals by $55 \%$, structure knowledge of scientific works by 40\%, technical knowledge of writing scientific papers by 50\%, and psychological and economic constraints by $50 \%$.
\end{abstract}

Keywords: training; teacher; scientific teacher

\section{Pendahuluan}

Salah satu kewajiban guru sesuai dengan Permen Menpan Nomor 16 Tahun 2009 dan Mendiknas Nomor 3/V/PB/2010 adalah memiliki publikasi karya ilmiah apabila ingin mengusulkan kenaikan pangkat dan persyaratan ini dimulai dari golongan 3A. Tuntutan ini mewajibkan para guru untuk dapat menghasilkan karya berupa karya tulis ilmiah. Menurut Brotowidjono (1985: 8-9) "karangan ilmiah adalah karangan ilmu pengetahuan yang menyajikan fakta dan ditulis menurut metodologi penulisan yang baik dan benar". Pendapat lain dari Wahyu (2001:61) yang mengatakan bahwa" suatu karangan dapat dikatakan ilmiah jika ia mengungkapkan suatu permasalahan dengan ilmiah". Menghasilkan tulisan ilmiah tentu berbeda dengan menulis karangan bebas. Terdapat aturan dan metode yang harus ditaati serta kemampuan untuk mentrasformasikan pikiran-pikiran menjadi tulisan ilmiah. Persyaratan menghasilkan tulisan karya ilmiah 
dan mempublikasikannya ini menjadi kekhawatiran tersendiri bagi sebagian guru. Terutama guru yang tidak dan belum terbiasa menulis karya ilmiah. Hal ini berakibat pada tidak meningkatnya jenjang karier guru.

Kendala umumnya adalah guru tidak memiliki cukup pengetahuan dasar atas hal-hal yang berhubungan dengan karya ilmiah dan publikasi karya ilmiah itu sendiri. Selain itu kurangnya motivasi juga menjadi kendala lain sebagian guru kesulitan dalam memenuhi publikasi karya ilmiah untuk kenaikan pangkat. Solusi atas kondisi tersebut adalah dengan dilaksanakannya pelatihan penulisan karya ilmiah yang harapannya dapat meningkatkan kemampuan guru tentang karya ilmiah dan sekaligus memenuhi persyaratan kenaikan pangkat yang berdampak pada kesejahteraan guru itu sendiri.

Pelaksanaan pelatihan penulisan karya ilmiah dapat dikatakan efektif, hal ini dibuktikan dengan pelatihan yang telah dilakukan oleh Casmudi dkk. dengan judul pelatihan; Upaya Peningkatan Penguasaan Guru SD dalam Penelitian Tindakan Kelas dan Penulisan Karya Tulis Ilmiah. Hasil dari pelatihan yang dimuat pada Jurnal Udayana Mengabdi: Vol 15, No 1 (2016) adalah terjadi peningkatan penguasaan guru setelah diadakannya pelatihan, pre-tes sebesar 43,64 \% dan post-tes sebesar 60,15\%. Selain itu terdapat pula pelatihan serupa yaitu oleh Hadiyati dkk. dengan judul Pelatihan Manajemen Penulisan Karya Tulis Ilmiah bagi Tenaga Pendidik Di SMPN 3 Kampar Kiri Tengah. Hasil dari pelatihan ini adalah adanya perubahan yaitu peningkatan atas pengetahuan, pemahaman dan ketrampilan guru dalam manajemen penulisan karya ilmiah.

Tim pelaksana juga akan melaksanakan pelatihan serupa dengan SMPN 7 Kota Bengkulu sebagai mitra kegiatan Pengabdian Pada Masyarakat. Perbedaan antara pelatihan yang telah dilakukan sebelumnya dengan pelatihan ini tampak dari target sasaran yang berbeda. Perbedaan target sasaran berarti berbeda pula masalah yang terdapat di dalamnya. Selain itu pelatihan ini fokusnya memberi pengetahuan tentang daftar referensi karya ilmiah, struktur karya ilmiah, dan juga point dalam menulis karya ilmiah. Tujuan dari diadakannya pelatihan ini adalah harapan atas peningkatan kualitas guru dalam kegiatan menulis karya ilmiah. Terhitung sejak 2011, setiap guru PNS yang mengajukan kenaikan pangkat harus bisa menulis karya ilmiah inovatif yang bernilai kredit poin. Kredit point inilah yang dikumpulkan oleh guru dan berguna untuk kenaikan jabatan.

Kewajiban yang harus dipenuhi yaitu dengan publikasi karya ilmiah oleh guru ini tidak berbanding lurus dengan apa yang terjadi di lapangan. Berdasarkan hasil survei awal yang didapat dari mewawancarai waka kurikulum dan para guru ditemukan kondisi bahwa minat menulis karya ilmiah guru-guru SMPN 7 Kota Bengkulu cukup tinggi namun mereka masih terkendala oleh minimnya pengetahuan dan keikutsertaan dalam pelatihan penulisan karya ilmiah. Tentu akibatnya adalah kurangnya publikasi ilmiah oleh guru, maka dari itu diperlukan pelatihan penulisan karya ilmiah untuk para guru di SMPN 7 Kota Bengkulu.

Sebelum memulai kegiatan pelatihan, tim pelaksana pengabdian telah mengadakan survei kepada para guru tentang pengetahuan dan minat menulis karya ilmiah guru-guru SMPN 7 Kota Bengkulu yang hasilnya cukup banyak guru yang berminat dalam penulisan karya ilmiah. Minat tersebut terkendala dengan minimnya pengetahuan dan keikutsertaan dalam pelatihan penulisan karya ilmiah. Tidak hanya kendala pengetahuan tentang struktur karya ilmiah, masalah psikologis seperti merasa tidak bisa, malu dan takut tulisan kurang baik atau ditertawakan orang lain, kurang termotivasi, dan kurangnya keinginan untuk maju. Hasil dari semua kendala tersebut adalah rendahnya publikasi karya ilmiah di jurnal-jurnal. Kendala-kendala yang tim pelaksana temukan ketika melakukan survei awal secara detail tergambar dalam diagram berikut. 


\section{Persentase Pengetahuan Guru SMPN 7 Kota Bengkulu atas Rendahnya Publikasi Karya Ilmiah}
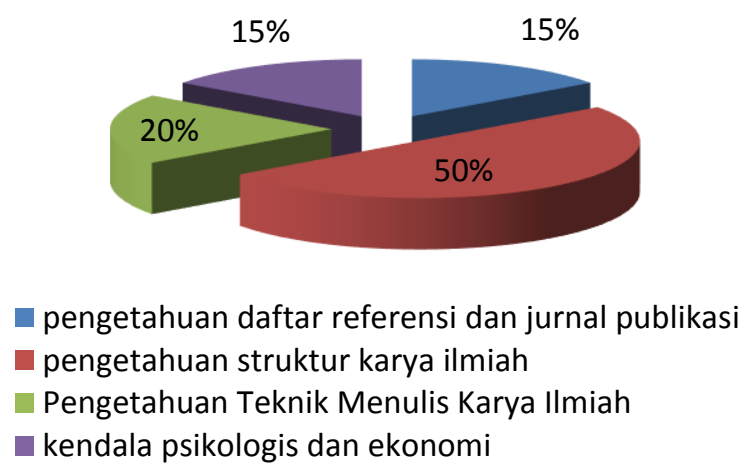

Gambar 1. Persentase pengetahuan peserta PkM

Dari diagram tersebut tergambar bahwa faktor utama masih rendahnya publikasi karya ilmiah oleh guru adalah kurangnya pengetahuan; 1) daftar referensi dan jurnal publikasi sebanyak 15\%,2) pengetahuan struktur karya ilmiah sebanyak 50\%,3) pengetahuan teknik menulis karya ilmiah sebesar 20\%, dan 4) kendala psikologis dan ekonomi sebesar 15\%. Berdasarkan hasil survei tersebut, maka tim pelaksana memutuskan SMPN 7 Kota Bengkulu sebagai mitra dan melaksanakan pengabdian di sekolah tersebut. Kegiatan Pelatihan Penulisan Karya Ilmiah diadakan untuk meningkatkan kemampuan guru di SMPN 7 Kota Bengkulu dalam pengetahuan dan praktek penulisan karya ilmiah.

Berdasarkan kendala yang ada maka dapat disimpulkan bahwa pengadaan pelatihan khusus oleh institusi Universitas Bengkulu sebagai acuan pendidikan tinggi di provinsi Bengkulu yang diwakili oleh tim pelaksana pengabdian untuk memfasilitasi guru-guru SMPN 7 Kota Bengkulu dalam meningkatkan keterampilan menulis karya ilmiah perlu dilakukan. Pengabdian yang berfokus pada memberi pengetahuan tentang daftar referensi karya ilmiah, struktur karya ilmiah, dan juga point dalam menulis karya ilmiah ini mengambil referensi dari buku berjudul Lincah Menulis Artikel Ilmiah oleh Purwana (2017) dan juga sumber-sumber internet lainnya yang dirangkum dalam slide power point yang akan di informasikan ketika pelatihan berlangsung.

\section{Metode}

Metode yang digunakan pada kegiatan ini adalah pelatihan untuk guru di SMPN 7 Kota Bengkulu. Pelatihan dilakukan untuk menambah pengetahuan dan wawasan guru tentang karya ilmiah dan penulisannya. Setelah guru sasaran menguasai pengetahuan tersebut, selanjutnya mereka diminta untuk menerapkan pengetahuan tersebut. Tim dosen akan mengarahkan, membimbing, dan membantu guru sasaran selama pelatihan dan setelah pelatihan jika para guru menginginkan tanya jawab diluar sesi pelatihan. Untuk mengevaluasi keberhasilan pelaksanaan pengabdian tim pelaksana menyiapkan angket yang akan dibagikan ketika pelatihan telah selesai dilakukan. Angket tersebut digunakan untuk mengetahui apakah terjadi perubahan setelah diadakannya pelatihan. Berikut adalah metode yang digunakan dalam pelatihan ini.

1) Ceramah dan Tanya Jawab. Metode ini dipilih untuk menjelaskan tentang materi yang bersifat teoritik terkait dengan aturan perundangan yang menyangkaut kenaikan pangkat menurut Peraturan Menteri Pendayagunaan Aparatur Negara dan Reformasi Birokrasi No. 16 Tahun 2006 Tentang Jabatan Fungsional Guru dan Angka Kreditnya yang mewajibkan kenaikan golongan dari III B ke III C harus mengumpulkan angka kredit minimal 4.

2) Demonstrasi. Metode ini digunakan untuk menjelaskan suatu proses kerja secara bertahap sehingga dapat memberi kemudahan bagi peserta untuk mengamati secara cermat proses pembuatan karya tulis ilmiah 


\section{Hasil dan Pembahasan}

Pelatihan Penulisan Karya Ilmiah untuk meningkatkan kemampuan guru di SMPN 7 Kota Bengkulu telah dilaksanakan pada hari Jumat, 6 September 2019. Awalnya kegiatan pengabdian ini direncanakan untuk 10 orang guru, namun karena antusiasme dari para guru SMP 7 Kota Bengkulu akhirnya jumlah peserta menjadi bertambah 3 orang dari yang telah direncanakan di awal. Sebenarnya jumlah peserta yang berminat untuk ikut pelatihan sekitar 25 orang guru namun karena kebijakan sekolah dan situasi siswa yang harus belajar membuat hanya sebagian guru yang dapat mengikuti acara pelatihan ini. Kegiatan ini dimulai pada pukul 08.00 WIB sampai dengan pukul 17.00 WIB. Peserta dalam kegiatan ini adalah dewan guru SMPN 7 Kota Bengkulu yang berjumlah 13 orag guru dengan berbagai macam bidang mata pelajaran.

Setelah acara dibuka, maka dilanjutkan dengan penyampaian materi pengabdian yaitu tentang pengetahuan penulisan karya ilmiah terkait dengan peningkatan kualitas menulis karya ilmiah guru untuk meningkatkan publikasi ilmiah oleh tim pelaksana pengabdian. Penyampaian materi pelatihan menggunakan media berupa infokus (LCD), fotokopi slide power point yang berisi materi mengenai pengetahuan penulisan karya ilmiah. Penyampaian materi pengabdian berkaitan dengan struktur karya ilmiah, teknik penulisan karya ilmiah, dan daftar referensi serta jurnal untuk mempublikasikan karya ilmiah. Berikut adalah beberapa materi yang disampaikan oleh tim pengabdi.

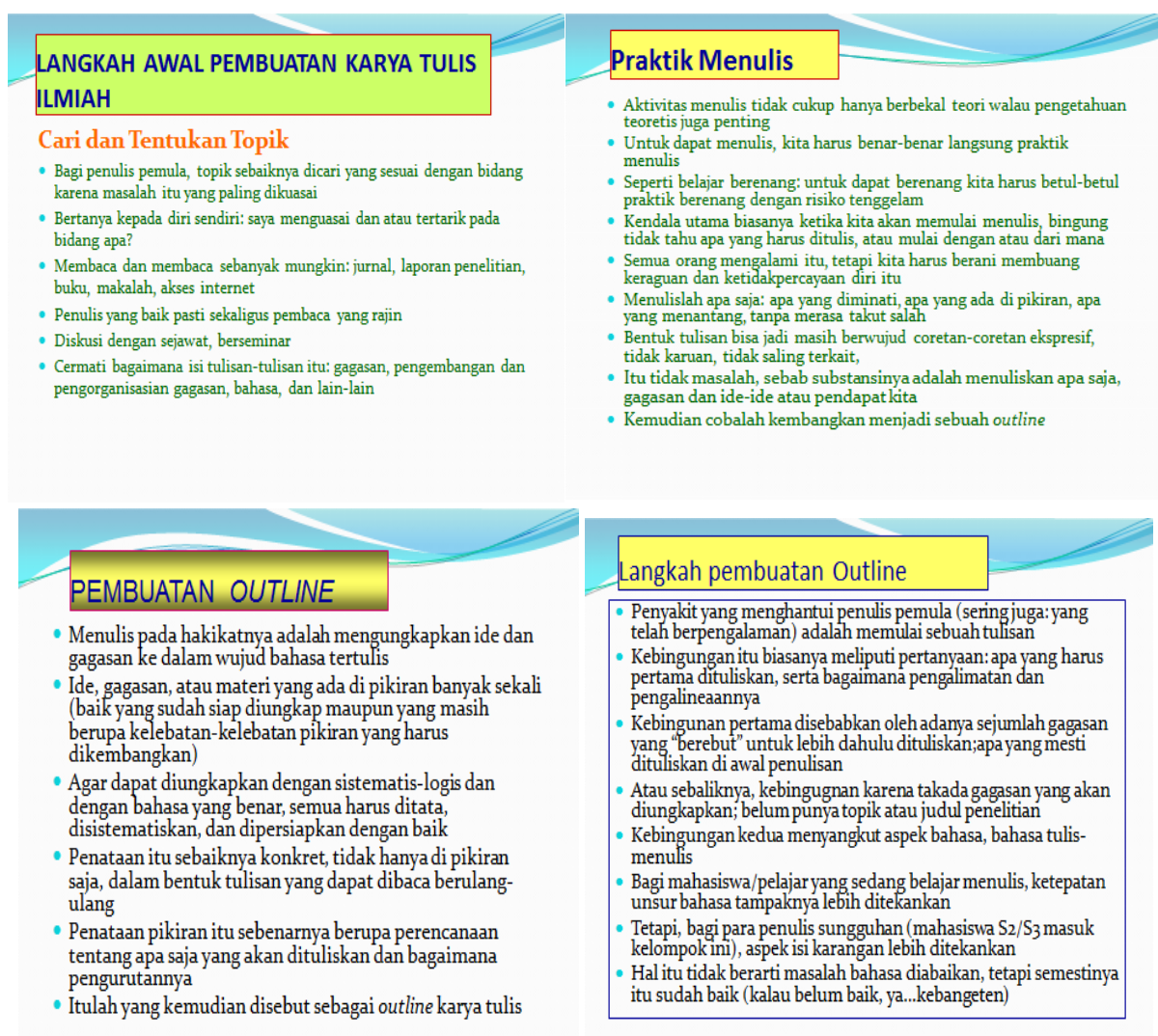

Gambar 2. Materi kegiatan

Selain beberapa materi diatas tim pengabdi juga memberikan informasi tentang alamat web yang mempublikasikan banyak tulisan ilmiah dari berbagai daerah. Alamat web yang dapat diakses sebagai referensi penulisan karya ilmiah diantaranya: 
Tabel 1.

Daftar laman referensi 1

\section{Alamat Web sebagai Referensi Penulisan Karya Ilmiah}

1. https://owl.english.purdue.edu/owl/resource/560/01/

2. http://www.conferencealerts.com/

3. http://id.portalgaruda.org/?ref=home

4. http://journal.asiatefl.org/

5. http://www.journal.tarbiyahiainib.ac.id/index.php/attalim

6. Jurnal Ling Tera.com

7. http://ejournal.upi.edu/index.php/IJAL/index

8. Pustaka ilmiah.com

Selain pengetahuan tentang alamat web yang banyak mempublikasikan tulisan ilmiah, tim pengabdi juga memberikan pengetahuan tentang laman web yang terkait dengan penulisan karya ilmiah mulai dari referensi penulisan karya ilmiah hingga cara pengecekan plagiasi sebuah karya ilmiah.

\begin{tabular}{|c|c|c|}
\hline 1 & www.scimagojr.com & $\begin{array}{l}\text { Salah satu laman jurnal internasional } \\
\text { bereputasi }\end{array}$ \\
\hline 2 & $\begin{array}{l}\text { http://scholarlyoa.com/publi } \\
\text { shers/ }\end{array}$ & melihat questionable journal dan publisher \\
\hline 3 & $\begin{array}{l}\text { www.microsoftacademicsear } \\
\text { ch.com }\end{array}$ & Salah satu laman jurnal internasional \\
\hline 4 & http://issn.lipi.go.id/ & cek issn \\
\hline 5 & www.doaj.com & melihat jurnal INA masuk list \\
\hline 6 & $\begin{array}{l}\text { www.plagiarisma.net, } \\
\underline{\mathrm{http}: / / \text { www.scanmyessay.co }} \\
\underline{\mathrm{m} /},\end{array}$ & $\begin{array}{l}\text { cek plagiat karya ilmiah di laman open access, } \\
\text { Plagiarisma dan viper }\end{array}$ \\
\hline 7 & $\begin{array}{l}\text { http://www.duplichecker.co } \\
\underline{\mathrm{m} /}\end{array}$ & $\begin{array}{l}\text { cek plagiat karya ilmiah dl laman open access } \\
\text { duplichecker }\end{array}$ \\
\hline 8 & www.ithenticate.com & idem no. 7 tapi termasuk laman subscribe \\
\hline
\end{tabular}

\begin{tabular}{|l|l|l|}
\hline 15 & $\begin{array}{l}\text { http://tejji.com/ip/url-to-ip- } \\
\text { address.aspx }\end{array}$ & $\begin{array}{l}\text { Laman untuk melihat lokasi } \\
\text { suatu URL dengan merobah ke } \\
\text { IP adress }\end{array}$ \\
\hline 16 & http://repec.org/ & $\begin{array}{l}\text { Laman utk melihat PT dan } \\
\text { penulis paling produktif } \\
\text { dibidang ekonomi }\end{array}$ \\
\hline 17 & http://www.harzing.com/pop.htm & $\begin{array}{l}\text { Laman utk melihat publikasi } \\
\text { dan paper. Harus di unduh } \\
\text { dahulu dan .exe di run }\end{array}$ \\
\hline 18 & OJS ( Open Journal System) & $\begin{array}{l}\text { Utk membuat jurnal on line, } \\
\text { free }\end{array}$ \\
\hline 19 & http://garuda.dikti.go.id/ & Portal garuda dikti \\
\hline 20 & http://id.portalgaruda.org & $\begin{array}{l}\text { IPI ( Indonesia Publication } \\
\text { Index)-IAES }\end{array}$ \\
\hline 21 & http://www.isbn-check.com/ & Cek ISBN \\
\hline
\end{tabular}

Gambar 3. Daftar laman referensi 2 (kiri) dan 3 (kanan)

Berikut adalah beberapa douemntasi kegiatan yang menunjukkan bagaimana kegiatan pelatihan ini berlangsung dimana peserta tampak antusias mengikuti materi yang diberikan saat tim pelaksana menyampaikan materi pengabdian.

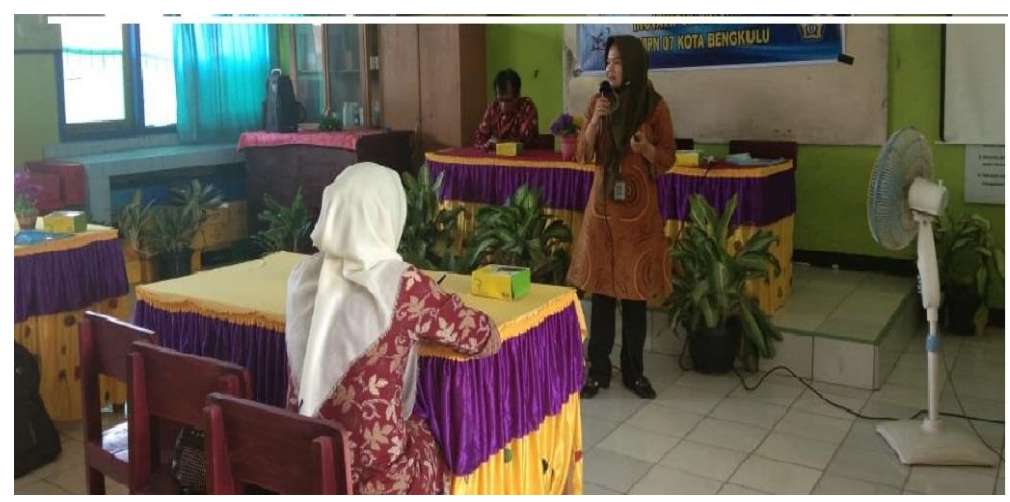

Gamabr 4. Tim pelaksana pengabdian menyampaikan materi kepada para guru SMPN 7 Kota Bengkulu 


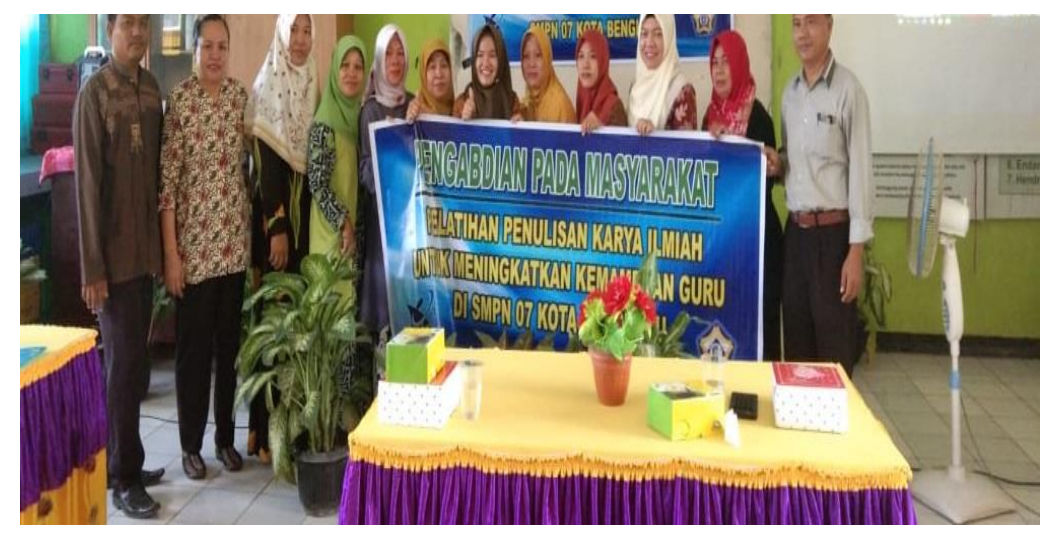

Gambar 5. Peserta pelatihan yang merupakan guru SMPN 7 Kota Bengkulu

Tidak hanya menyampaikan materi mengenai karya ilmiah tetapi kegiatan pengabdian ini juga diisi dengan kegiatan tanya jawab dengan para peserta perihal teknis pelaksanaan dalam penerapan penulisan karya ilmiah. Kendala-kendala yang sering ditemui guru dalam pelaksanaan menulis karya ilmiah atau mempublikasikan karya ilmiah juga dibahas secara bersama-sama pada sesi ini. Selanjutnya dilaksanakan praktek menulis kerangka karya ilmiah oleh seluruh peserta pelatihan. Dalam melaksanakan kegiatan pengabdian, tim pengabdi juga menemukan beberapa faktor yang mendukung dan menghambat kegiatan.

Faktor yang mendukung kegiatan adalah antusiasme peserta untuk memahami konsep penulisan karya ilmiah untuk peningkatan kualitas guru dan peningkatan jenjang karier guru. Hal-hal tersebutlah yang membuat kegiatan pelatihan ini dapat berjalan dengan lancar. Antusiasme tampak dari banyaknya pertanyaan yang muncul ketika pelaksanaan tanya jawab. Para guru tampak sangat penasaran dengan cara agar tulisan ilmiah yang mereka buat dapat di publikasi di jurnal. Maka dari itu tim pelaksana jg menyampaikan pengetahuan perihal beberapa jurnal yang dimiliki oleh FKIP.

Selain faktor pendukung terdapat pula faktor pengahmbar dalam pelaksanaan pelatihan ini. Tim pelaksana merasa bersalah atas keinginan beberapa guru yang tidak tercapai untuk dapat ikut serta dalam pelatihan dikarena harus melaksanakan kewajiban mengajar. Namun kebijakan sekolah untuk membatasi jumlah guru yang antusias ingin ikut serta dalam pelaksanaan pengabdian dikarena demi kepentingan pembelajaran siswa di kelas. Selain ada hambatan lain yaitu guru yang pamit keluar-masuk untuk mengecek kelas yang mereka tinggal sehingga materi yang didapat guru tersebut pun tidak utuh karena tertinggal saat keluar ruangan. Namun faktor penghambat tersebut bukan halangan dalam mewujudkan kegiatan pelatihan penulisan karya ilmiah.

Pemilihan karya ilmiah sebagai materi dalam pelatihan ini agar dapat meningkatkan kualitas guru sekaligus meningkatkan profesionalitas guru sehigga jenjang kariernya pun meningkat. Peraturan yang berlaku terhitung sejak tanggal 1 Januari 2013 yaitu Permen Menpan Nomor 16 Tahun 2009 dan Mendiknas Nomor 3/V/PB/2010 tentang aturan perhitungan angka kredit jabatan serta petunjuk pelaksanaan jabatan fungsional guru secara tersurat mengatakan bahwa bahwa guru wajib mempunyai publikasi karya ilmiah jika ingin mengusulkan kenaikan pangkat mulai dari golongan 3A.

Survei awal yang menunjukkan bahwa guru-guru di SMPN 7 kota Bengkulu masih kurang memahami hal-hal yang berkaitan dengan karya ilmiah akhirnya menuntut tim pelaksana pengabdian untuk melaksanakan pengabdian yaitu pelatihan penulisan karya ilmiah untuk guru-guru SMPN 7 Kota Bengkulu. Tujuan dilaksanakannya pengabdian ini adalah agar dapat memberikan pengetahuan pada para guru 
mengenai penulisan karya ilmiah. Penulisan itu pada akhirnya akan mengarahkan peserta untuk melakukan publikasi ilmiah untuk mememuhi syarat kenaikan pangkat oleh pemerintah. Jadi bukan banya dari segi pengetahuan saja para guru bertambah tetapi juga meningkatnya karier guru.

Pada akhir pelaksanaan pengabdian, tim pelaksana membagikan angket yang sama dengan angket awal yang telah dibagikan kepada para guru sebagai alat yang digunakan untuk mengukur seberapa besar capaian peningkatan pengetahuan peserta sebelum dan setelah pelatihan dilaksanakan. Angket tersebut berisi beberapa pertanyaan yang berkaitan dengan; (1) teknik penulisan karya ilmiah, (2) struktur karya ilmiah, (3) referensi dan daftar jurnal karya ilmiah serta (4) pengetahuan tentang memotivasi kendala dalam bidang psikologis dan ekonomis dalam penulisan karya ilmiah. Berdasarkan evaluasi dari angket pertama dan angket akhir yang tim pelaksana berikan kepada para guru tampak terjadi peningkatan persentase atas pengetahuan peserta atas penulisan karya ilmiah. Peningkatan tersebut tergambar pada tabel berikut:

Tabel 2.

Persentase pengetahuan peserta sebelum dan sesudah pelatihan

\begin{tabular}{|c|c|c|c|c|}
\hline \multirow[b]{2}{*}{ No } & \multirow[b]{2}{*}{ Indikator Penilaian } & Sebelum Pelatihan & Setelah Pelatihan & \multirow[b]{2}{*}{ Ratio Peningkatan } \\
\hline & & $\begin{array}{l}\text { Persentase tingkat } \\
\text { pemahaman }\end{array}$ & $\begin{array}{l}\text { Persentase tingkat } \\
\text { pemahaman }\end{array}$ & \\
\hline 1 & $\begin{array}{l}\text { Pengetahuan daftar referensi } \\
\text { dan jurnal publikasi }\end{array}$ & $15 \%$ & $70 \%$ & $55 \%$ \\
\hline 2 & $\begin{array}{l}\text { Pengetahuan struktur karya } \\
\text { ilmiah }\end{array}$ & $50 \%$ & $90 \%$ & $40 \%$ \\
\hline 3 & $\begin{array}{l}\text { Pengetahuan teknik menulis } \\
\text { karya ilmiah }\end{array}$ & $20 \%$ & $70 \%$ & $50 \%$ \\
\hline 4 & $\begin{array}{l}\text { Kendala psikologis dan } \\
\text { ekonomi }\end{array}$ & $15 \%$ & $65 \%$ & $50 \%$ \\
\hline
\end{tabular}

Berdasarkan data pada tabel tersebut diketahui bahwa ada peningkatan pemahaman peserta pelatihan pada aspek pengetahuan daftar referensi dan jurnal publikasi, struktur karya ilmiah, pengetahuan teknik menulis karya ilmiah, dan kendala psikologis dan ekonomi. Untuk indikator aspek pengetahuan daftar referensi dan jurnal publikasi, terjadi peningkatan yang cukup drastis yaitu sebelum pelatihan $15 \%$ dan setelah pelatihan menjadi 70\%. Artinya untuk indikator tersebut terjadi peningkatan sebanyak $55 \%$. Hal berbeda terjadi untuk indikator pengetahuan struktur karya ilmiah yang sedari awal dipahami hampir setengah peserta. Saat sebelum pelatihan, persentase yang di dapat yaitu $50 \%$ dan setelah pelatihan dilaksanakan, persentase pun meningkat menjadi $90 \%$. Aspek pengetahuan teknik menulis karya ilmiah dan kendala psikologi dan ekonomi juga mengalami peningkatan. Pada aspek teknik menulis karya ilmiah awalnya persentasenya adalah $20 \%$ yang kemudian meningkat menjadi $70 \%$. Lalu untuk aspek kendala psikologi dan ekonomi yang awalnya $15 \%$ meningkat menjadi $65 \%$.

\section{Kesimpulan}

Kegiatan pengabdian masyarakat berjudul "Pelatihan Penulisan Karya Ilmiah untuk Meningkatkan Kemampuan Guru Di SMPN 7 Kota Bengkulu" berjalan dengan lancar. Kesimpulannya adalah pengabdian berhasil dan bermanfaat bagi peserta pelatihan. Respon positif dari peserta merupakan indikator kuat bahwa pelatihan ini adalah pelatihan yang diharapkan oleh para guru sebab dapat bermanfaat baik dalam meningkatkan kegiatan belajar mengajar di kelas dan peningkatan pengajaran guru agar ebih mumpuni. Selain itu, keberhasilan ini juga ditunjukkan dengan adanya kesesuaian materi dengan kebutuhan guru dalam meningkatkan kualitas diri dan jenjang kariernya. 
JURNAL ANUGERAH. November 2019; I(1): 33- 40

Harapan dari diadakannya pelatihan ini dapat meningkatkan kualitas guru dan memotivasi guru untuk menulis dan mempublikasikan karya ilmiah. Proses kegiatan pengabdian seperti tanggapan, dan pertanyaan peserta pengabdian, saran yang dapat diberikan adalah agar guru dapat mengembangkan motivasinya dalam menulis karya ilmiah dan mempublikasikannya di jurnal. Diharapkan pelatihan ini dapat meningkatkan kualitas guru dan memotivasi guru untuk menulis dan mempublikasikan karya ilmiah.

\section{Referensi}

Brotowidjoyo, Mukayat D. (1985). Penulisan Karangan Ilmiah. Jakarta: Akademika Presindo.

Casmudi dkk. (2016). Upaya Peningkatan Penguasaan Guru SD dalam Penelitian Tindakan Kelas dan Penulisan Karya Tulis Ilmiah. Jurnal Udayana Mengabdi: Vol 15, No $1 . \quad$ DOI: 10.36277/abdimasuniversal.v1i1.13

Depdiknas Dirjen Dikdasmen Direktorat Tenaga Kependidikan.(2001). Pedoman Penyusunan Karya Tulis Ilmiah di Bidang Pendidikan dan Angka Kredit Pengembangan Profesi Guru. Jakarta:2001.

Hadiyati dkk. (2017). Pelatihan Manajemen Penulisan Karya Tulis Ilmiah bagi Tenaga Pendidik Di SMPN 3 Kampar Kiri Tengah. Jurnal Dinamisia, Vol 1 No 1. DOI: 10.31849/dinamisia.v1i1.425

Permendiknas No. 18 Tahun 2007.

Pemenpan Nomor 84/1993 tentang Kepangkatan.

Peraturan Menteri Pendayagunaan Aparatur Negara dan Reformasi Birokrasi No. 16 Tahun 2009,(2009). Tentang Jabatan Fungsional Guru dan Angka Kreditnya.

Purwarna, D. (2017). Lincah Menulis Artikel Ilmiah Populer \& Jurnal. Jakarta: Grafindo Persada.

Undang-Undang Republik Indonesia Nomor 4 Tahun 20005 tentang guru dan dosen.

Undang-Undang RI Nomor 14 Tahun 2005.

Wahyu, Wibowo. (2001). Managemen Bahasa Pengorganisasian Karangan Pragmatik dalam Bahasa Indonesia untuk Mahasiswa dan Praktisi Bisnis. Jakarta: Gramedia Pustaka Utama 